\title{
Binding Affinity of Candesartan, Losartan, Telmisartan and Valsartan with Angiotensin II Receptor 1 Subtype
}

\author{
Mohiuddin Ahmed Bhuiyan ${ }^{1}$, Mohammad Shahriar ${ }^{2}$ and Takafumi Nagatomo ${ }^{1}$ \\ ${ }^{1}$ Department of Pharmacology, Niigata University of Pharmacy and Applied Life Sciences, Niigata, Japan \\ ${ }^{2}$ Department of Pharmacy, University of Asia Pacific, Dhanmondi, Dhaka, Bangladesh
}

\begin{abstract}
This study was designed to examine the interaction in the binding of selective angiotensin II receptor antagonists towards angiotensin II type 1 receptor. The $\mathrm{AT}_{1}$ antagonists used in this study were valsartan, candesartan and losartan. Wild type $\mathrm{AT}_{1}$ receptors were transiently expressed in COS-7 cells and the expressed protein was isolated. The binding affinities of agonist and these four $\mathrm{AT}_{1}$ antagonists were determined towards $\mathrm{AT}_{1}$ receptors with the help of radioligand binding studies. The binding affinity of candesartan has been found to be maximum having a $\mathrm{pKi}$ value of $8.61 \pm 0.21$ whereas losartan showed lowest binding affinity among the antagonists $(\mathrm{pKi}=7.17 \pm 0.07)$. Telmisartan also showed high $(\mathrm{pKi}=8.19 \pm 0.04)$ and valsartan had moderate binding affinity $(\mathrm{pKi}=7.65 \pm 0.12)$ towards $\mathrm{AT}_{1}$ receptors. The results of the study suggested that candesartan interacts very strongly with the receptor which is consistent with the maximum number of binding sites of in the chemical structure of candesartan. On the other hand, losartan has lower number of binding sites with the amino acid residues of $\mathrm{AT}_{1}$ receptor and as a result it showed the minimum affinity towards the receptor.
\end{abstract}

Key words: Binding affinity, $\mathrm{AT}_{1}$ antagonists, radioligand binding, binding sites.

\section{Introduction}

G-protein coupled receptors (GPCRs) form one of the largest protein families, with several hundred members in humans. The Angiotensin II (Ang II) receptors are the members of the G-protein coupled receptor (GPCR) superfamily, which form one of the largest protein families, with several hundred members in human (Venter et al., 2001). Despite the wide variety of ligands and physiological roles, all these receptors are structurally characterized by seven transmembrane domains. Two subtypes of Ang II receptors have been identified (Whitebread et al., 1989; Chiu et al., 1989) and functionally characterized: Ang II type $1\left(\mathrm{AT}_{1}\right)$ and type 2 $\left(\mathrm{AT}_{2}\right)$ receptors (Bumpus et al., 1991). $\mathrm{AT}_{1}$ receptor mediates virtually all the known physiological actions of Ang II, including vascular contraction, aldosterone secretion, sodium and water retention, neuronal activation, and cardiovascular cell growth and proliferation (De Gasparo et al., 2000; Burnier, 2001). $\mathrm{AT}_{1}$ receptor is an important target for drug development, as the abnormalities in its function are linked to hypertension, water-electrolyte imbalance, hyperaldosteronism, cardiac hypertrophy, and heart failure (Peach, 1977). Ang II receptor blockers (ARBs) are highly selective for $\mathrm{AT}_{1}$ receptor. In addition to their blood pressure-lowering effects, ARBs have been shown to promote regression of left ventricular hypertrophy and decrease cardiovascular morbidity and mortality in patients with heart failure or hypertensive diabetic nephropathy with proteinuria (De Gasparo et al., 2000).

Ang II binds to $\mathrm{AT}_{1}$ receptor and induces cell signaling accompanied by changes in the transmembrane (TM 3- TM 6) conformation (Ghanouni et al., 2001). $\mathrm{AT}_{1}$ receptor binds a peptide ligand and does not share significant overall homology with other receptors of the seven-transmembrane domain family. Peptide antagonists have higher affinity toward the $\mathrm{AT}_{1}$ receptor, suggesting that they bind in a unique conformation to the receptor (Noda et al., 1995). In this study, we determined the binding affinity of different non-peptide $\mathrm{AT}_{1}$ antagonists with wild type $\mathrm{AT}_{1}$ receptors using $\left[{ }^{3} \mathrm{H}\right]$-Angiotensin II as radioligand and confirmed the same with the number of binding sites of the ligands.

\section{Materials and Methods}

Drugs: Candesartan was obtained as gift from Takeda Chemical Industries Ltd, Osaka, Japan. Losartan was obtained from Merck Research Laboratories, USA. 
Valsartan was a gift from Novartis Institutes for BioMedical Research, Inc, Cambridge. Telmisartan was obtained from Nippon Boehringer Ingelheim, Japan. Angiotensin II human used in the study was purchased from Peptide Institute Inc. Osaka, Japan.

DNA constructs: The cDNA clone for human $\mathrm{AT}_{1}$ receptor was obtained from the UMR cDNA Resource Center, Missouri, USA. The $\mathrm{AT}_{1}$ receptor cDNA was cloned into the pcDNA3.1+ (Invitrogen, CA, USA) at EcoRI $\left(5^{\prime}\right)$ and Xhol $\left(3^{\prime}\right)$ for expression. Receptor plasmid was prepared using Miniprep kit (Biorad, CA, USA) after transformation of DH- $5 \alpha$ cells through electroporation.

Cell culture and transfection: COS-7 cells were cultured in Dulbecco's Modified Eagle's medium (DMEM) supplemented with 10\% fetal bovine serum, 100 $\mathrm{U} / \mathrm{ml}$ penicillin, and $100 \mu \mathrm{g} / \mathrm{ml}$ streptomycin. Stably expressing cell lines were constructed in COS-7 cells by transfecting with Lipofectamine ${ }^{\mathrm{TM}} 2000$ reagent and selecting with G418-containing growth medium as detailed by the manufacturer's protocol (Invitrogen Life Technologies, Rockville, MD, USA).

Membrane preparation: Stably transfected COS-7 cells were grown in $10-\mathrm{cm}$ plates. The confluent plates were harvested with ice-cold phosphate buffer saline (PBS), pH 7.4, washed by HBSS with $1.5 \% 0.5$ M EDTA, $0.15 \% 50 \mathrm{mg} / \mathrm{ml} \mathrm{PMSF}$ and $0.15 \% 2 \mathrm{mg} / \mathrm{ml}$ aprotinin, and finally suspended in $0.25 \mathrm{M}$ sucrose solution containing $1.5 \% 0.5 \mathrm{M}$ EDTA, $0.15 \% 50 \mathrm{mg} / \mathrm{ml}$ PMSF and $0.15 \% 2$ $\mathrm{mg} / \mathrm{ml}$ aprotinin. The cells were then disrupted by Polytron Homogenizer for 10 seconds. The mass was centrifuged at $4^{\circ} \mathrm{C}$ for 5 minutes at $1260 \mathrm{~g}$ and the supernatant was ultra centrifuged at $4^{\circ} \mathrm{C}$ for 20 minutes at $30,000 \mathrm{~g}$. The resulting pellets were suspended in binding assay buffer and used for binding experiments. The protein contents of the membrane concentrations were measured by the method of Lowry et al. (1951) using bovine serum albumin as the standard.

Radioligand binding assay: $\mathrm{AT}_{1}$ receptor binding assay was carried out in incubation tube that contained 10 $\mu \mathrm{g}$ of membrane protein, $\left[{ }^{3} \mathrm{H}\right]$-Angiotensin II (Perkin Elmer Life and Analytical Sciences, Boston, MA, USA), unlabeled drug as required and binding buffer in a final volume of $125 \mu \mathrm{l}$. Both saturation and competition binding assays were carried out as described previously (Miura et al. 2006; John et al. 2001). Briefly, for saturation binding studies, six to seven concentrations (5-800 pM) of $\left[{ }^{3} \mathrm{H}\right]-$
Angiotensin II were tested in duplicate. Nonspecific binding was defined as the amount of radioligand binding remaining in presence of $10 \mu \mathrm{M}$ human angiotensin II. For competition binding studies, membranes were incubated with $250 \mathrm{pM}$ of $\left[{ }^{3} \mathrm{H}\right]$-Angiotensin II and unlabelled drugs for $1 \mathrm{hr}$ at $25^{\circ} \mathrm{C}$. The incubation was terminated by rapid filtration under vacuum through Whatman $\mathrm{GF} / \mathrm{C}$ filters that had been presoaked in $0.5 \%$ polyethyleneimine followed by three times washing with $4 \mathrm{ml}$ ice-cold 50 $\mathrm{mM}$ tris $\mathrm{HCl}(\mathrm{pH} \mathrm{8.0)}$. The radioactivity retained on the filters was measured by liquid scintillation spectrophotometry.

Data Analysis: Nonlinear regression analyses of saturation and competition binding assay were performed using GraphPad Prism software (San Diego, CA, USA). The results of experiments were expressed as the mean \pm S.E.M. In competition binding experiments, the values of inhibition constants $\left(\mathrm{K}_{\mathrm{i}}\right)$ were calculated by the following equation (Cheng and Prusoff 1973):

$$
\mathrm{K}_{\mathrm{i}}=\mathrm{IC}_{50} /\left\{1+\left([\mathrm{L}] / \mathrm{K}_{\mathrm{d}}\right)\right\}
$$

where, the inhibition concentrations $\left(\mathrm{IC}_{50}\right)$ were determined as the concentrations of ligands that inhibited $\left[{ }^{3} \mathrm{H}\right]$-Angiotensin II binding by $50 \%$; [L] $=$ the concentration of $\left[{ }^{3} \mathrm{H}\right]$-Angiotensin II used and $\mathrm{K}_{\mathrm{d}}=$ the dissociation constant of $\left[{ }^{3} \mathrm{H}\right]$-Angiotensin II for the receptor. Statistical analyses were performed by the Student's unpaired $t$-test (two tailed).

\section{Results and Discussion}

Radioligand binding experiments for cloned $A T_{1}$ receptor: In saturation experiment, specific binding of $\left[{ }^{3} \mathrm{H}\right]$-Angiotensin II was determined using the cloned $\mathrm{AT}_{1}$ receptor subtype. The affinity constant $\left(\mathrm{K}_{\mathrm{d}}\right)$ was $509.7 \pm$ $18.5 \mathrm{pM}$ and the receptor density $\left(\mathrm{B}_{\max }\right)$ for the membrane was $670.7 \pm 39.8 \mathrm{fmol} / \mathrm{mg}$ protein. Table 1 shows the binding affinities $\left(\mathrm{pK}_{\mathrm{i}}\right)$ for $\mathrm{AT}_{1}$ receptor antagonists in which candesartan showed maximum binding affinity towards wild type $\mathrm{AT}_{1}$ receptor and losartan had the lowest value. Telmisartan also showed high affinity whereas valsartan had moderate affinity towards the receptor.

In saturation binding experiment, the data represent the different level of cell expression of wild type $\mathrm{AT}_{1}$ receptor. The binding affinity of the drug to receptor depends upon the interaction between the functional group of ligand and the receptor protein. The mechanism of 
binding of antagonists to human $\mathrm{AT}_{1}$ receptor is still not well understood. However, some reports have been published showing the important sites of interaction with different antagonists in $\mathrm{AT}_{1}$ receptor (Miura et al. 2006; Underwood et al. 1994; Verheijen et al. 2000, 2003). In our previous study we identified the binding sites of nonpeptide Ang II receptor antagonists with $\mathrm{AT}_{1}$ receptor by molecular modeling (Bhuiyan et al., 2009). There it was shown that candesartan has a maximum of four binding sites interacting with the receptor. The carboxylate group and the ethoxy group of candesartan play a very important role in binding with the receptor in addition to the biphenyl tetrazole ring. Valsartan and losartan has three and two sites respectively. The results of the competition binding studies thus correspond to the previous findings

A)

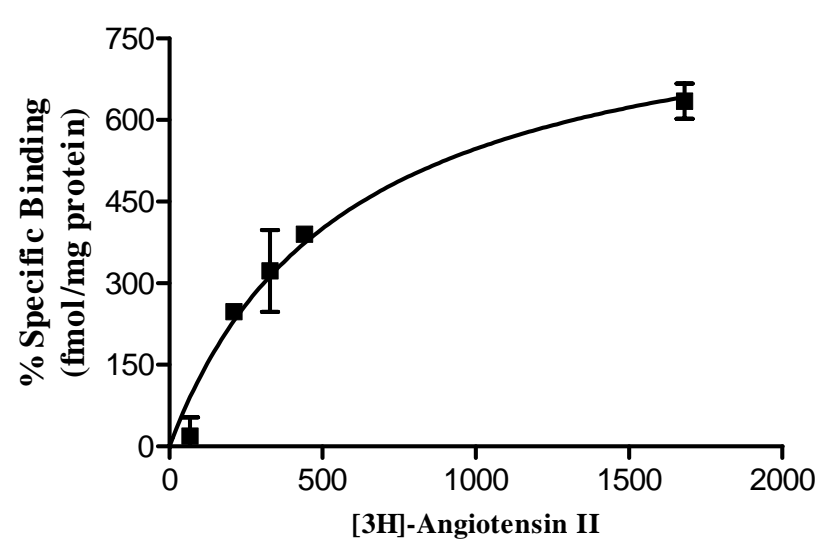

although the binding affinity of telmisartan was found to be irrespective to binding sites (Figure 1).

Table 1. Agonist and antagonist binding affinities for $\left[{ }^{3} \mathrm{H}\right]-$ Angiotensin II labeled $\mathrm{AT}_{1}$ receptor

\begin{tabular}{lc}
\hline & $\mathrm{AT}_{1}$ receptor \\
\hline Agonist & $\mathrm{pKi}$ \\
Human Angiotensin II & $7.61 \pm 0.23(4)$ \\
\hline Antagonist & \\
Candesartan & $8.61 \pm 0.21(4)$ \\
Losartan & $7.17 \pm 0.07(4)$ \\
Telmisartan & $8.19 \pm 0.04(4)$ \\
Valsartan & $7.65 \pm 0.12(4)$ \\
\hline
\end{tabular}

The data shown indicate the mean \pm SEM of $\mathrm{pK}_{\mathrm{i}}$ values and numbers in parentheses indicate the number of experiments.

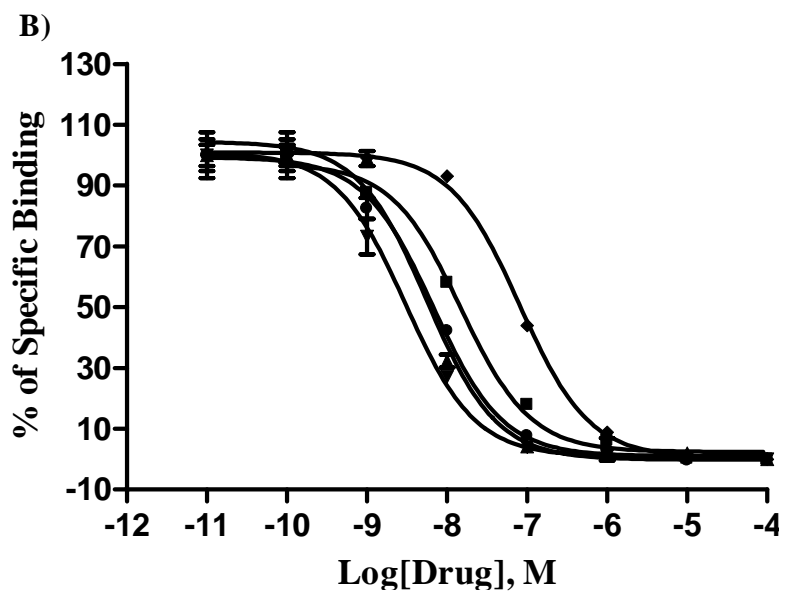

Figure 1. (A) Saturation analysis of $\mathrm{AT}_{1}$ wild-type receptor labeled with $\left[{ }^{3} \mathrm{H}\right]$ - Angiotensin II. (B) Competition binding studies of Ang II (square) and $\mathrm{AT}_{1}$ receptor antagonists candesartan (triangle), valsartan (inverted triangle), losartan (diamond), and telmisartan (circle) for $\left[{ }^{3} \mathrm{H}\right]$ - Angiotensin II binding to wild-type $\mathrm{AT}_{1}$ receptor. The data represent the mean \pm S.E.M. of four different experiments each performed in duplicate.

\section{Conclusion}

In summary, the number of the binding sites of losartan may be smallest of the antagonists of this study, being consistent with the lowest binding affinity of losartan. In addition, candesartan would have another extra hydrogen bond with the receptor. The number of interacting sites is consistent with the higher binding affinity of candesartan than valsartan. As telmisartan also showed high binding affinity towards $\mathrm{AT}_{1}$ receptor, the carboxylate group may have profound role in binding between the ligand and the receptor. The number of the hydrogen bonds between the ligands and the receptor may thus correspond to the order of the binding affinity of the antagonists.

\section{References}

Bhuiyan, M.A., Ishiguro, M., Hossain, M., Nakamura, T., Ozaki, M., Miura, S. and Nagatomo, T. 2009. Binding sites of valsartan, candesartan and losartan with angiotensin II receptor 1 subtype by molecular modeling. Life Sciences $\mathbf{8 5}$, 136-140.

Bumpus, F.M., Catt, K.J., Chiu, A.T., DeGasparo, M., Goodfriend, T., Husain, A., Peach, M.J., Taylor, D.G. Jr. and Timmermans, P.B.M.W.M. 1991. Nomenclature for angiotensin receptors. A report of nomenclature committee of the council for high blood pressure research. Hypertension 17, 720-721.

Burnier, M. 2001. Angiotensin II type 1 receptor blockers. Circulation 103, 904-912. 
Cheng, Y.C. and Prusoff, W.H. 1973. Relationship between the inhibition constant $(\mathrm{Ki})$ and the concentration of inhibition, which causes $50 \%$ inhibition $\left(\mathrm{IC}_{50}\right)$ of an enzymatic reaction. Biochem. Pharmacol. 22, 3099-3108.

Chiu, A.T., Herblin, W.F., McDall, D.E., Ardecky, R.J., Carini, D.J., Duncia, J.V., Pease, L.J., Wong, P.C., Wexler, R.R., Johnson, A.L. and Timmermans, P.B.M.W.M. 1989. Identification of angiotensin receptor subtypes. Biochem. Biophys. Res. Commun. 165, 196-203.

De Gasparo, M., Catt, K.J., Inagami, T. and Unger, T.H. 2000. The Internation Union of Pharmacology: The angiotensin II receptors. Pharmacol. Rev. 52, 415-472.

Ghanouni, P., Steenhuis, J.J., Farrens, D.L.and Kobilka, B.K. 2001. Agonist-induced conformational changes in the Gprotein-coupling domain of the beta 2 adrenergic receptor. Proc. Natl. Acad. Sci. 98, 5997-6002.

John, H., Jennifer, N.H,, Steven, J.F. and Daniel, K.Y. 2001. Identification of angiotensin II type 2 receptor domains mediating high-affinity CGP 42112A binding and receptor activation. J. Pharmacol. Exp. Ther. 298, 665-673.

Lowry, O.H., Rosebrough, N.J., Farr, A.L. and Randall, R.J. 1951. Protein measurement with the Folin phenol reagent. $J$. Biol. Chem. 193, 265-275,

Miura, S., Fujino, M., Hanazawa, H., Kiya, Y., Imaizumi, S., Matsuo, Y., Tomita, S., Uehara, Y., Karnik, S.S., Yanagisawa, H., Koike, H., Komuro, I. and Saku, K. 2006. Molecular mechanism underlying inverse agonist of angiotensin II type I receptor. J. Biol. Chem. 281, 1928819295.
Noda, K., Saad, Y., Kinoshita, A., Boyle, T.P., Graham, R.M. and Husain, A. 1995. Tetarzole and carboxylate groups of angiotensin receptor antagonists bind to the same subside by different mechanisms. J. Biol. Chem. 270, 2284-2289.

Peach, M.J. 1977. Renin-angiotensin system. Biochemistry and mechanisms of action. Physiological Rev. 57, 313-370.

Underwood, D.J., Strader, C.D., Rivero, R., Patchett, A.A., Greenlee, W. and Prendergast, K. 1994. Structural model of antagonist and agonist binding to the angiotensin II, $\mathrm{AT}_{1}$ subtype, G protein coupled receptor. Chemistry \& Biology 1, 211-21.

Venter, J.C., Adams, M.D., Myers, E.W., Li, P.W., Mural, R.J. and Sutton, G.G. 2001. The sequence of the human genome. Science 291, 1304-1351.

Verheijen, I., Fierens, F.L.P., De Backer, J.P., Vauquelin, G. and Vanderheyden, P. 2000. Interaction between the partially insurmountable antagonist valsartan and human recombinant angiotensin II type 1 receptors. Fund. Clin. Pharmacol. 14, 577-585.

Verheijen, I., De Backer, J.P., Vanderheyden, P. and Vauquelin, G. 2003. A two-state model of antagonist-AT 1 receptor interaction: further support by binding studies at low temperature. Biochem. Pharmacol. 65, 1339-41.

Whitebread, S., Mele, M., Kamber, B. and De Gasparo, M. 1989. Preliminary biochemical characterization of two angiotensin II receptor subtypes. Biochem. Biophys. Res. Commun. 163, 284-291. 